\title{
ANALISIS DAMPAK PEMBIAYAAN QARDUN HASAN TERHADAP KESEJAHTERAAN PEDAGANG DI ACEH
}

\author{
Damanhur \& Wahyudiah Utami \\ ${ }^{1}$ Program Studi Ekonomi Syariah Fakultas Ekonomi dan Bisnis Universitas Malikussaleh \\ Email Corespondent : damanhur@unimal.ac.id
}

\begin{abstract}
The purpose of this study was to analyze the Impact of Qardun Hasan Financing on the Well-Being of Traders in the Lambaro Banda Aceh market. The data used in this study are primary data using sequential time data. The number of samples in this study were 34 members of the Banda Aceh Baitul Misyakat Sharia Cooperative whose receipts were traders in the Lambaro Banda Aceh market using accidental sampling techniques. Data obtained through interviews and questionnaires. The method of data analysis in this study used a paired t test method. The results of this study found that there was an impact on the welfare of traders as measured by religious activity, income, savings and alms. The four indicators showed an impact on the welfare of traders, this was concluded after looking at the conditions and data of traders before and after receiving Qardun Hasan's financing.
\end{abstract}

Keywords : Qardun Hasan Financing; Welfare; Religious Activities; Income; Savings and Alms

\begin{abstract}
Abstrak: Tujuan penelitian ini adalah untuk melihat Dampak Pembiayaan Qardun Hasan Terhadap Kesejahteraan Pedagang Dipasar Lambaro Banda Aceh. Adapun data yang digunakan dalam penelitian ini adalah data primer dengan menggunakan data runtut waktu. Jumlah sampel dalam penelitian ini sebanyak 34 orang anggota Koperasi Syariah Baitul Misyakat Banda Aceh yang notabenenya adalah pedagang dipasar Lambaro Banda Aceh dengan menggunakan teknik accidental Sampling. Data didapatkan melalui hasil wawancara dan Kuisioner. Metode analisis data dalam penelitian ini menggunakan metode uji beda berpasangan (paired t test). Hasil penelitian ini menemukan bahwa terdapat dampak terhadap kesejahteraan pedagang yang diukur melalui indikator kegiatan keagamaan, pendapatan, tabungan, dan sedekah. Keempat indikator tersebut masing-masing menunjukkan adanya dampak terhadap kesejahteraan pedagang, hal ini disimpulkan setelah melihat kondisi dan data pedagang sebelum dan setelah menerima pembiayaan Qardun Hasan.
\end{abstract}

Keywords : Pembiayaan Qardun Hasan, Kesejahteraan, Aktivitas Keagamaan, Pendapatan, Tabungan dan Sedekah. 


\section{PENDAHULUAN}

Indonesia merupakan salah satu negara yang memiliki penduduk dengan mayoritas beragama Islam terbesar di dunia, sebanyak $85 \%$ dari 265 Juta penduduk Indonesia adalah pemeluk agama Islam (Sensus Penduduk, 2018).

Dalam konteks perekonomian atau yang berhubungan dengan muamalah, aktivitas pinjam meminjam (uang) sudah menjadi hal yang sangat lumrah. Dimana, pinjam meminjam menjadi instrumen yang diandalkan manusia untuk menggerakkan laju perekonomian secara mikro yang biasanya dilakukan dengan akad pembiayaan.

Dalam islam, terdapat instrumen pembiayaan yang bisa digunakan dalam rangka tolong menolong atau berbuat kebajikan, artinya pembiayaan yang dilakukan tanpa adanya unsur bunga (riba), melainkan peminjam hanya mengembalikan pokok pinjamannya saja setelah waktu yang disepakati atau biasa disebut dengan pinjaman kebajikan.Nama instrument pembiayaan itu ialah pembiayaan qardun hasan.

Qardun Hasan merupakan gabungan dari kata Qard dan Hasan. Secara etimologi, qard berarti potongan, sedangkan pengertian secara terminologi berarti pemberian harta kepada orang lain yang dapat diminta kembali dengan jumlah yang sama atau dengan kata lain meminjamkan tanpa mengharapkan imbalan atau tambahan. Kata "hasan" berasal dari bahasa arab yaitu "ihsan" yang artinya kebaikan kepada orang lain. Qardun Hasan yaitu jenis pinjaman yang diberikan kepada pihak yang sangat memerlukan untuk jangka waktu tertentu tanpa harus membayar bunga atau keuntungan. Penerima Qardun Hasan hanya berkewajiban melunasi jumlah pinjaman pokok tanpa diharuskan memberikan tambahan apapun. Namun, penerima pinjaman boleh saja atas kebijakannya sendiri membayar lebih dari uang yang dipinjamnya sebagai tanda terima kasih kepada pemberi pinjaman. Tetapi hal tersebut tidak boleh diperjanjikan sebelumnya di muka.

Sistem pembiayaan / pinjaman permodalan Qardun Hasan merupakan kebalikan atau lawan dari sistem pinjaman berbunga (riba) yang dilarang dalam islam yang biasanya di aplikasikan oleh rentenir. Dalam Kamus Besar Bahasa Indonesia $(\mathrm{KBBI})$, rentenir berarti orang yang mencari nafkah dengan membungakan uang, tukang riba, pelepas uang, lintah darat. Dalam situs resmi Departemen Koperasi (saat ini Kementrian Koperasi dan Usaha Kecil dan Menengah) disebutkan rentenir adalah seseorang atau kelompok orang yang memiliki profesi sebagai pemberi pinjaman uang kepada para petani kecil (misalnya di kawasan Asia) dengan tingkat bunga yang jauh lebih tinggi daripada tingkat bunga yang resmi di pasar, bahkan, terkadang sedemikian tingginya sampai terasa mencekik leher.

Dalam Islam, praktik rentenir adalah sama dengan istilah mu'amalat ribawiyah, yaitu tambahan terhadap modal uang yang timbul akibat suatu transaksi utang-piutang yang harus diberikan oleh peminjam kepada pemilik uang pada saat hutang jatuh tempo.Hal ini sangat dilarang dalam Islam sebagaimana Firman Allah dalam QS. Annisa: 161: "Dan disebabkan mereka memakan riba, padahal sesungguhnya mereka telah dilarang dari padanya, dan karena mereka memakan harta benda orang dengan cara yang batil, kami telah menyediakan tempat untuk orang-orang yang kafir diantara mereka itu siksa yang pedih".

Praktik rentenir (riba) di Pasar Lambaro Kabupaten Aceh Besar, telah terjadi dari tahun 2000. Awalnya para rentenir berasal dari wilayah luar Aceh, namun pada saat ini sebagian pelaku merupakan orang Aceh. Kondisi tersebut sangat memprihatinkan, mengingat nilai keislaman orang Aceh cukup kuat. Dari hasil survey pasar, praktik ribawi yang dilakukan para rentenir kepada para pedagang dikenakan bunga yang cukup tinggi yakni mencapai $185 \%$ (efektif rate) per tahun. Apabila seseorang meminjam sebesar Rp.1.000.000 maka yang bersangkutan harus mengembalikan sejumlah Rp.1.200.000 dalam waktu 40 hari dengan angsuran Rp. 30.000 per harinya. Apabila dihitung dengan perhitungan bunga efektif, maka diperoleh beban bunga yang dikenakan adalah diatas $185 \%$ pertahunnya, sungguh suatu angka yang sangat tragis dan menyebabkan pedagang jauh dari kesejahteraan.

Kesejahteraan adalah sebuah tata kehidupan dan penghidupan sosial, material, maupun spiritual yang diikuti dengan rasa keselamatan, kesusilaan dan ketentraman diri, rumah tangga serta masyarakat lahir dan batin yang memungkinkan setiap warga negara dapat melakukan usaha pemenuhan kebutuhan jasmani, rohani dan sosial yang sebaik-baiknya bagi diri sendiri, rumah tangga, serta masyarakat dengan menjunjung tinggi hak-hak asasi (Purwandi, 2014)

Seiring berjalannya waktu, kondisi maraknya praktik ribawi yang menjadi salah satu faktor penghambat kesejahteraan para pedagang dipasar Lam Baro kabupaten Aceh Besar yang sangat memprihatinkan ini, akhirnya mendapat perhatian oleh para pengusaha yang tergabung dalam jamaah pengajian Indonesia Islamic Business Forum wilayah Aceh. Pada tanggal 13 Januari 2016, Para pengusaha tersebut mendirikan sebuah koperasi syariah yang diberi nama "Kopsyah Baitul Misyakat" dengan jumlah anggota untuk pertama kali berjumlah 29 orang.

Koperasi Syariah dilihat dari segi bahasa, secara umum koperasi berasal dari kata-kata latin 
yaitu, cum yang berarti dengan, dan apareri yang berarti kerja. Dari dua kata ini, dalam bahasa inggris dikenal dengan istilah co dan operation yang dalam bahasa Belanda disebut dengan istilah Cooperation veregening yang berarti bekerja sama dengan orang lain untuk mencapai suatu tujuan tertentu. Sedangkan secara etimologi, koperasi ialah suatu perkumpulan atau organisasi yang beranggotakan orang-orang atau badan hukum yang bekerja sama dengan penuh kesadaran untuk meningkatkan kesejahtraan anggota atas dasar sukarela secara kekeluargaan. Jadi bisa difahami bahwa koperasi syariah adalah organisasi yang beranggotakan orang-orang atau badan hukum yang bekerja sama dengan penuh kesadaran untuk meningkatkan kesejahtraan anggota atas dasar sukarela secara kekeluargaan yang dilaksanakan berdasarkan prinsip syariah islam yang berasal dari Al-qur'an dan Assunnah.

Koperasi Syariah dilihat dari segi bahasa, secara umum koperasi berasal dari kata-kata latin yaitu, cum yang berarti dengan, dan apareri yang berarti kerja. Dari dua kata ini, dalam bahasa inggris dikenal dengan istilah co dan operation yang dalam bahasa Belanda disebut dengan istilah Cooperation veregening yang berarti bekerja sama dengan orang lain untuk mencapai suatu tujuan tertentu. Sedangkan secara etimologi, koperasi ialah suatu perkumpulan atau organisasi yang beranggotakan orang-orang atau badan hukum yang bekerja sama dengan penuh kesadaran untuk meningkatkan kesejahtraan anggota atas dasar sukarela secara kekeluargaan. Jadi bisa difahami bahwa koperasi syariah adalah organisasi yang beranggotakan orang-orang atau badan hukum yang bekerja sama dengan penuh kesadaran untuk meningkatkan kesejahtraan anggota atas dasar sukarela secara kekeluargaan yang dilaksanakan berdasarkan prinsip syariah islam yang berasal dari Al-qur'an dan Assunnah.

Eksistensi "Kopsyah Baitul Misykat" yang didirikan oleh para pengusaha yang tergabung dalam jamaah pengajian Indonesia Islamic Business Forum wilayah Aceh tersebut, bertujuan untuk memberantas praktik ribawi yang dilakukan oleh para rentenir terhadap para pedagang dipasar. Adapun upaya yang dilakukan adalah dengan cara menawarkan dan menganjurkan para pedagang menggunakan pembiayaan/pinjaman kebajikan atau istilah islam yang biasa disebut ialah pembiayaan Qardun Hasan. Para pedagang yang diberikan pinjaman/pembiayaan Qardun Hasan, selanjutnya akan diberikan arahan untuk wajib mengikuti kajian rutin/pengajian secara berkala.

Dari upaya yang dilakuan Kopsyah Baitul Misykat ini, hal-hal yang ingin dilihat adalah apakah Qardun Hasan bisa memutuskan tali rantai rentenir, apakah Qardun hasan bisa berdampak terhadap kesejahteraan pedagang yang diukur dari iman (kajian rutin),pendapatan, tabungan dan sedekah. Dari permasalahan yang dipaparkan diatas, maka penulis tertarik untuk melakukan penelitian dengan judul "ANALISIS DAMPAK PEMBIAYAAN QARDUN HASAN TERHADAP KESEJAHTERAAN PEDAGANG ACEH", Studi kasus pada penelitian ini yaitu para pedagang di Pasar Lambaro Kabupaten Aceh Besar.

\section{TINJAUAN PUSTAKA}

\section{Pengertian Qardun Hasan}

Al-Qardh Al-Hasan merupakan gabungan dari dua kata, al-qardh danal-hasan. Menurut bahasa atau menurut etimologi al-qardh berasal dari kata $a l$-qat' $u$ yang berarti potongan. Harta yang dibayarkan kepada muqtarid (yang diajak qardh), dinamakan dengan qardh karena pemilik memotong sebahagian hartanya untuk diperdagangkan dan memperoleh sebagian keuntungannya. Al-qardh secara bahasa juga bisa diartikan dengan sebagian pinjaman atau hutang, sedangkan al-hasan artinya baik. Apabila digabungkan al-qardh al-hasan berarti pinjaman yang baik.

Dalam menjelaskan al-qardh al-hasan para ahli fiqh muamalah menggunakan istilah qardh, karena istilah al-qardh al-hasan tidak ditemukan dalam literatur fiqh muamalah. Namun demikian, maka qardh yang dimaksudkan oleh mereka itulah al-qardh al-hasan. Sedangkan menurut terminologi atau istilah, antara lain dikemukakan oleh ulama Hanafiah, Qardh adalah"Akad tertentu dengan membayarkan harta mitsil kepada orang lain supaya membayar harta yang sama kepadanya"

Menurut Syafi'i Antonio,al-qardh adalah pemberian harta kepada orang lain yang dapat ditagih atau diminta kembali atau meminjamkan tanpa mengharapkan imbalan. Sedangkan menurut Bank Indonesia,qardh adalah akad pinjaman dari bank (muqridh) kepada pihak tertentu (muqtaridh) yang wajib dikembalikan dengan jumlah yang samasesuai pinjaman.

Jadi, al-qardh adalah suatu aqad perjanjian antara penghutang dengan peminjam yang melakukan utang dan piutang. Dalam aqad tersebut, miliknya kepada peminjam dalam waktu tertentu. Peminjam juga berjanji akan membayar kembali kepada penghutang sama seperti nilai harta yang dipinjamkannya dan tidak lebih daripada itu. Jadi dari beberapa definisi diatas dapat disimpulkan bahawa Al qardh Al Hasan adalah pinjaman 
kebajikan (tabarru') bukan untuk tujuan komersil (tijarah).

\section{Rukun dan Syarat Qardun Hasan} sebagai berikut:

Adapun rukun dari Qardun Hasan adalah

1. Orang yang meminjam pinjaman (Muqtaridh)

2. Pihak yang memberi pinjaman (muqridh)

3. Objek akad yang merupakan pinjaman yang dipinjamkan oleh pemilik kepada pihak yang menerima pinjaman (dana/qard)

4. Ijab qabul (sighat) perkataan yang diucapkan oleh pihak yang menerima pinjaman dari orang yang memberi barang pinjaman atau ucapan yang mengandung adanya izin yang menunjukkan kebolehan untuk mengambil manfaat dari pihak yang menerima pinjaman.

Sementara itu, syarat dari Qardun Hasan adalah sebagai berikut:

1. Orang yang meminjamkan memenuhi syarat berikut :

a. Berhak berbuat kebaikan sekehendak orang tersebut

b. Manfaat dari barang yang dipinjamkan menjadi milik peminjam dan barang yang dipinjamkan menjadi milik yang meminjamkan.

2. Orang yang meminjam :

a. Berhak mendapat kebaikan

b. Dapat dipercaya untuk menjaga barang tersebut

3. Barang yang dipinjamkan :

a. Mempunyai manfaat yang dapat diambil oleh peminjam

b. Barang yang diambil manfaatnya tidak rusak karena pemakaian yang disetujui dalam perjanjian.

Ulama hanafiyah berpendapat bahwa qard dipandang sah pada harta mitsil, yaitu sesuatu yang tidak terjadi perbedaan yang menyebabkan terjadinya perbedaan nilai. Diantara yang dibolehkan adalah benda-benda yang ditimbang, ditakar, atau dihitung.

4. Lafadz atau ijab kabul :

a. Lafadz Kalimat mengutangkan

b. Mu'ir (orang yang mengutangkan) merupakan pemilik barang tersebut, dan musta'ir (orang yang berhutang) harus baligh, berakal, dan bukan orang yang tidak dimahjur.

c. Benda yang diutangkan dapat diambil manfaatnya atau dimanfaatkan.

\section{Manfaat Qardun Hasan}

Riswandi (2015), menurut pendapat paling

Unggul Hanafiyah, setiap qardun hasan pada benda yang mendatangkan manfaat diharamkan jika memakai syarat. Ulama Malikiyah berpendapat bahwa muqridh tidak boleh memanfaatkan harta muqtaridh, seperti naik kendaraan atau makan dirumah muqtaridh, jika dimaksudkan untuk membayar hutang Muqridh bukan sebagai penghormatan. Begitu pula dilarang memberikan hadiah kepada muqridh, jika dimaksudkan untuk menyicil hutang.

Ulama Syafi'iyah dan Hanbaliah melarang al-qardal-hasan terhadap sesuatu yang mendatangkan kemanfaatan, seperti memberikan qaradh agar mendapat sesuatu yang lebih baik atau lebih banyak sebab qaradh dimaksudkan sebagai akad kasih sayang, kemanfaatan, atau mendekatkan hubungan kekeluargaan. Rasulullah SAW. Pun melarangnya. Namun demikian, jika tidak disyaratkan atau tidak dimaksudkan untuk mengambil yang lebih baik, Qardun hasan dibolehkan. Tidak dimakruhkan bagi muqridh untuk mengambilnya, sebab Rasulullah SAW. pernah memberikan anak unta yang lebih baik kepada seorang laki-laki dari pada unta yang diambil Beliau SAW. Selain itu Jabir bin Abdullah barkata:"aku memiliki hak pada rasulullah SAW., kemudian beliau membayarnya dan menambah untukku."

\section{Pengertian Kesejahteraan}

Kesejahteraan menurut Badan Pusat Statistik (2019) adalah suatu kondisi dimana seluruh kebutuhan jasmani dan rohani dari rumah tangga tersebut dapat dipenuh sesuai dengan tingkat hidup. Status kesejahteraan dapat diukur berdasarkan proporsi pengeluaran rumah tangga (Bappenas, 2019).

Kesejahteraan adalah sebuah tata kehidupan dan penghidupan sosial, material, maupun spiritual yang diikuti dengan rasa keselamatan, kesusilaan dan ketentraman diri, rumah tangga serta masyarakat lahir dan batin yang memungkinkan setiap warga negara dapat melakukan usaha pemenuhan kebutuhan jasmani, rohani dan sosial yang sebaik-baiknya bagi diri sendiri, rumah tangga, serta masyarakat dengan menjunjung tinggi hak-hak asasi (Rambe, 2004).

\section{Pengertian Iman}

Iman berasal dari Bahasa Arab dari kata dasar amana yu'minu-imanan. Artinya beriman atau percaya. Percaya dalam Bahasa Indonesia artinya meyakini atau yakin bahwa sesuatu (yang dipercaya) itu memang benar atau nyata adanya.Iman dapat dimaknai iktiraf, membenarkan, mengakui, pembenaran yang bersifat khusus. 
Bila kita perhatikan penggunaan kata Iman dalam Al-Qur'an, akan mendapatinya dalam dua pengertian dasar, yaitu:

1. Iman dengan pengertian membenarkan ( ال تصدي ق) adalah membenarkan berita yang datangnya dari Allah dan Rasul-Nya. Dalam salah satu hadist shahih diceritakan bahwa Rasulullah ketika menjawab pertanyaan Jibril tentang Iman yang artinya bahwa yang dikatakan Iman itu adalah engkau beriman kepada Allah, malaikat-Nya, kitabkitab-Nya, Rasul-rasul-Nya, hari kiamat dan engkau beriman bahwa Qadar baik dan buruk adalah dari Allah SWT.

2. Iman dengan pengertian amal atau ber-iltizam dengan amal : segala perbuatan kebajikan yang tidak bertentangan dengan hukum yang telah digariskan oleh syara'.

\section{Pengertian Pendapatan}

Pendapatan adalah sejumlah penghasilan yang diperoleh masyarakat atas prestasi kerjanya dalam periode tertentu, baik harian, mingguan, bulanan maupun tahunan (Sukirno, 2006). Rahardja dan Manurung (2001) mengemukakan pendapatan adalah total penerimaan (uang dan bukan uang) seseorang atau suatu rumah tangga dalam periode tertentu. Berdasarkan kedua definisi tersebut, dapat disimpulkan bahwa pendapatan merupakan penghasilan yang diterima oleh masyarakat berdasarkan kinerjanya, baik pendapatan uang maupun bukan uang selama periode tertentu, baik harian, mingguan, bulanan maupun tahunan.

\section{Pengertian Tabungan}

Tabungan merupakan simpanan yang paling populer dikalangan masyarakat umum lain dari masyarakat kota sampai pedesaan. Menurut Undang-Undang Perbankan No.10 Tahun 1998, tabungan adalah simpanan yang penarikannya hanya dapat dilakukan menurut syarat tertentu yang disepakati, tetapi tidak dapat ditarik dengan cek, bilyet giro, atau alat lainnya yang dipersamakan dengan itu.

Undang-undang Nomor 21 Tahun 2008 yang memberikan rumusan pengertian tabungan, yaitu Tabungan adalah simpanan berdasarkan akad wadiah atau investasi dana berdasarkan akad mudharabah atau akad lain yang tidak bertentangan dengan prinsip syariah yang penarikannya hanya dapat dilakukan menurut syarat dan ketentuan tertentu yang disepakati tetapi tidak dapat ditarik dengan cek, bilyet giro atau alat lainnya yang dipersamakan dengan itu.

\section{Pengertian Sedekah}

Sedekah berasal dari kata sadaqa yang berarti benar. Orang yang gemar bersedekah bisa diartikan sebagai orang yang benar pengakuan imannya. Menurut istilah atau terminologi syariat, sedekah yaitu mengeluarkan sebagian harta atau pendapatan / penghasilan untuk suatu kepentingan yang diperintahkan oleh agama. Sedekah juga merupakan pemberian yang dikeluarkan secara sukarela kepada siapa saja, tanpa nisab dan tanpa adanya aturan waktu yang mengikat (Sanusi, 2009). Sedekah berarti sesuatu yang diberikan dengan tujuan mendekatkan diri pada Allah.

Menurut Syara', sedekah atau shadaqoh berarti memberi kepemilikan pada seseorang pada waktu hidup dengan tanpa imbalan sesuatu dari yang diberi serta ada tujuan taqorrub pada Allah SWT. Sedekah juga diartikan memberikan sesuatu yang berguna bagi orang lain yang memerlukan bantuan (fakir-miskin) dengan tujuan untuk mendapat pahala.

Menurut Retnowati (2007), sedekah itu berarti menyisihkan sebagian harta yang dimilikinya untuk diberikan kaum fuqara walmasakin atau orang yang berhak mendapatkannya dengan hati yang ikhlas dan mengharap dari ridha Allah. Pemberian kepada orang lain, baik bersifat materi maupun nonmateri secara sukarela, tanpa nisab, dan bisa dilakukan kapan pun dan dimana pun, serta kepada siapa pun tanpa aturan dan syarat, kecuali untuk mengharapkan ridho Allah.

\section{Pengertian Koperasi Syariah}

Dilihat dari segi bahasa, secara umum koperasi berasal dari kata-kata latin yaitu, cum yang berarti dengan, dan apareri yang berarti kerja. Dari dua kata ini dalam bahasa inggris dikenal dengan istilah co dan operation yang dalam bahasa Belanda disebut dengan istilah Cooperation veregening yang berarti bekerja sama dengan orang lain untuk mencapai suatu tujuan tertentu.sedangkan secara etimologi, koperasi ialah suatu perkumpulan atau organisasi yang beranggotakan orang-orang atau badan hukum yang bekerja sama dengan penuh kesadaran untuk meningkatkan kesejahtraan anggota atas dasar sukarela secara kekeluargaan.

Istilah bekerja sama berdasarkan atas asas kekeluargaan, secara otentik juga digunakan dalam konstitusi negara UUD 1945 sebagai tipologi sistem perekonomian nasional. Dalam penjelasannya, istilah usaha bersama berdasarkan atas asas kekeluargaan disebut koperasi. Dalam UndangUndang 25 Tahun 1992 dinyatakan bahwa yang dimaksud koperasi adalah badan usaha yang beranggotakan orang-orang atau badan hukum koperasi dengan melandaskan kegiatannya berdasarkan prinsip koperasi sekaligus sebagai 
gerakan ekonomi rakyat berdasar atas asas kekluargaan.

Dalam perjalanannya koperasi yang sebanarnya sangat sesuai dengan jiwa bangsa Indonesia justru perkembangannya tidak mengembirakan. Koperasi yang dianggap sebagai anak kandung dan tulang punggung ekonomi kerakyatan justru hidupnya timbul tenggelam, sekalipun pemerintah telah berjuang keras untuk menghidupkan dan memberdayakan koperasi di tengah-tengah masyarakat. Begitu banyak kemudahan yang diperoleh oleh badan hukum koperasi melalui berbagai fasilitas, namun tidak banyak mengubah kehidupan koperasi itu sendiri.

\section{Hipotesis Penelitian}

Beberapa studi sebelumnya juga membahas Qardun Hasan, tetapi hal tersebut masih jarang dilakukan di kalangan peneliti. Menurut Mirachor \& Iqbal (2007), ketika Qardun Hasan memiliki fleksibelitas dan hal tersebut memberikan dampak terhadap kesejahteraan pedagang-pedagang kecil. Febianto \& Ashany (2015) menemukan bahwa Qardun Hasan menjadi alat pembiayaan yang tepat dalam meningkatkan pemberdayaan ekonomi masyarakat. Amin et al. (2010) menemukan bahwa sikap dan norma subjektif menjadi faktor yang mampu mempengaruhi peningkatan pembiayaan Qardun Hasan pada Bank Syariah di Malaysia. Assegaff et al. (2016) mendokumentasikan bahwa Pemberdayaan dapat diwujudkan dengan Qardun Hasan, terkhusus pada negara-negara maritime seperti di Indonsesia. Ashal \& Nanda (2018) menemukan bahwa skema pembiayaan Qardun Hasan dapat meningkatkan kesejahteraan masyarakat, seperti meningkatnya aktivitas keagamaan, meningkatkan pendapatan dan tabungan, terbentuknya iklim-iklim salin tolong menoling dan terciptanya kominitas yang agamis sehingga masyarakat dapat menolak segala pembiayaan yang mengandung riba. Sari (2013) berpendapat bahwa Qardun Hasan berkorelasi positif dengan pendapatan usaha. Hardi (2013) mendokumentasi bahwa Qardun Hasan berdampak terhadap perilaku bersedekah individu. Berdasarkan hal tersebut, menunjukkan bahwa Qardun Hasan dapat meningkatkan aktivitas keagamaan, pendapatan, tabungan dan sedekah, sehingga hipotesis yang dibangun dalam penelitian ini adalah sebagai berikut:

H1 : Terdapat perbedaan signifikan antara aktivitas keagamaan pedagang sebelum dan sesudah menerima pembiayaan Qardun Hasan
H2 : Terdapat perbedaan signifikan antara pendapatan pedagang sebelum dan sesudah menerima pembiayaan Qardun Hasan

H3 : Terdapat perbedaan signifikan antara tabungan pedagang sebelum dan sesudah menerima pembiayaan Qardun Hasan

H4 : Terdapat perbedaan signifikan antara sedekah pedagang sebelum dan sesudah menerima pembiayaan Qardun Hasan

\section{METODE PENELITIAN}

\section{Data}

Jenis data yang digunakan dalam penelitian ini adalah data primer, yang merupakan jawaban 34 pedagang di Pasar Lambaro yang tercatat sebagai anggota di Koperasi Syariah Baitul Misykat Kabupaten Aceh Besar, Provinsi Aceh, Indonesia. Untuk mendapatkan informasi, data-data, serta keteranganketerangan yang diperlukan dalam penelitian ini, penulis menggunakan metode pengumpulan data primer yaitu dengan wawancara dan angket penelitian.

\section{Operasionalisasi Variabel}

Adapun definisi operasional dari seluruh variabel yang digunakan dalam penelitian ini adalah sebagai berikut:

\section{Qardun Hasan}

Qardun Hasan merupakan Akad pemberian pinjaman tanpa adanya imbalan atau bisa dikatakan pinjaman yang bersifat tolong menolong dan bukan untuk kepentingan komersil. Peminjam hanya mengembalikan pokok pinjamannya saja kepada si pemberi pinjaman pada pada waktu yang telah disepakati. Variabel ini diukur dengan jumlah Qardun Hasan yang diberikan dalam satuan Full Rupiah.

2. Kesejahteraan

Dalam penelitian ini, kesejahteraan diukur dengan 4 indikator utama, yaitu sebagai berikut:

a. Kegiatan Keagamaan

yaitu segala aktifitas kegiatan agama Islam yang bisa menambah keimanan dan ketaqwaan seseorang kepada Allah SWT. Variabel ini diukur dengan frekuensi responden mengikuti kajian selama sebulan

b. Pendapatan

Yaitu sejumlah penghasilan yang diperoleh masyarakat atas prestasi kerjanya dalam periode tertentu, baik harian, mingguan, bulanan maupun tahunan. Indikator ini diukur dengan 
jumlah pendapatan perbulan dalan Satuan Full Rupiah

c. Tabungan yaitu Kemampuan dan kesediaan untuk menahan nafsu konsumsi selama beberapa waktu agar dimasa depan terbuka kemungkinan konsumsi yang memuaskan. Indikator ini diukur dengan jumlah tabungan per bulan dalam satuan Full Rupiah

d. Sedekah

yaitu mengeluarkan sebagian harta atau pendapatan / penghasilan untuk suatu kepentingan yang diperintahkan oleh agama. Sedekah juga merupakan pemberian yang dikeluarkan secara sukarela kepada siapa saja, tanpa nisab dan tanpa adanya aturan waktu yang mengikat. Variabel ini diukur dengan jumlah sedekah per bulan dalam satuan Full Rupiah

\section{Metode Analisis}

Metode analisis data yang digunakan uji beda berpasangan (piared $t$ test). Piared $t$ test merupakan uji dua sampel berpasangan yang bertujuan untuk melihat adakah perbedaan secara nyata pada dua sampel tersebut (Ghozali, 2016). Uji piared $t$ test adalah salah satu metode pengujan hipotesis dimana data yang digunakan tidak bebas (berpasangan). Ciri-ciri yang paling sering ditemui pada kasus yang berpasangan adalah satu individu (objek penelitian) dikenai 2 buah perlakuan yang berbeda. Walaupun menggunakan individu yang sama, peneliti tetap memperoleh 2 macam data sampel, yaitu data dari perlakuan pertama dan data dari perlakuan kedua. Perlakuan pertama bisa saja berupa kontrol, yaitu tidak memberikan perlakuan sama sekali tidak terhadap objek penelitian (Siegel, 2007).

\section{HASIL DAN PEMBAHASAN}

\section{Analisis Deskriptif Responden}

Klasifikasi responden dalam penelitian ini adalah meliputi jenis kelamin, tingkat pendidikan terakhir, kondisi hunian dan tipe hunian. Untuk lebih jelasnya karakteristik responden dapat dilihat pada Tabel 1 di bawah ini:
Tabel 1. Analisis Deskriptif Responden

\begin{tabular}{ccc}
\hline \multicolumn{2}{c}{ Klasifikasi } & Persentasi \\
\hline Gender & \\
1. & Laki-Laki & $0 \%$ \\
2. & Perempuan & $100 \%$ \\
\hline Tingkat Pendidikan & \\
1. & Tidak sekolah & $2,9 \%$ \\
2. & SD/Sederajat & $35,3 \%$ \\
3. & SMP/Sederajat & $17,6 \%$ \\
4. & SMA/Sederajat & $44,1 \%$ \\
\hline Kondisi Hunian & \\
1. $\quad$ Milik Sendiri & $79,4 \%$ \\
2. Milik Keluarga & $17,6 \%$ \\
3. Sewa & $2,9 \%$ \\
\hline Tipe Hunian & \\
1. Permanen & $32.4 \%$ \\
2. Semi Permanen & $20.6 \%$ \\
3. Kayu & $47.1 \%$ \\
\hline
\end{tabular}

Sumber : Data Diolah, 2019

Berdasarkan Tabel 1 di atas, ditemukan bahwa responden dalam penelitian ini keseluruhan adalah perempuan. Selanjutnya, responden didominasi oleh pedagang yang berpendidikan tamat SMA/Sederajat sebanyak 44,1\%. Responden dalam penelitian ini juga didominasi oleh pedagang yang memiliki rumah sendiri sebanyak $79,4 \%$ dan didominasi oleh pedagang dengan tipe huniannya kayu sebanyak $47,1 \%$

\section{Analisis Deskriptif Statistic}

Pada analisis deskriptif statistik pada penelitian ini, akan terlihat bagaimana rata-rata (mean) dan standar deviasi (std dev). Hal ini bertujuan untuk melihat pergerakan data di dalam penelitian. Adapun hasil analisis deskriptif dalam penelitian ini adalah sebagai berikut:

Tabel 2 Analisis Deskriptif Statistik




Berdasarkan Tabel 2 di atas, untuk aktivitas keagamaan, nilai rata-rata sebelum menerima Qardun Hasan sebesar 0,44 kali dalam seminggu sedangkan setelah menerima Qardun Hasan menjadi 4 kali dalam seminggu dimana hal tersebut mengalami peningkatan. Pendapatan sebelum menerima Qardun Hasan memiliki ratarata sebesar $\mathrm{Rp} 4,173,529.41$ sedangkan setelah menerima Qardun Hasan meningkat dengan ratarata sebesar $\mathrm{Rp} 7,500,000.00$. Tabungan sebelum pembiayaan Qardun Hasan memiliki rata-rata Rp 708,823.53 dan meningkat setelah menerima Qardun Hasan dengan rata-rata sebesar $\mathrm{Rp}$ 1,086,764.71. Hal yang sama juga terjadi pada Shadaqah, diman sebelum menerima pembiayaan Qardun Hasan rata-ratanya hanya sebesar $\mathrm{Rp}$ 54,705.88 kemudian meningkat menjadi Rp 102,352.94. Secara keseluruh, kegiatan keagamaan, pendapatan, tabungan dan shadaqah pada pedagang mengalami peningkatan setelah menerima pembiayaan Qardun Hasan.

\section{Pengujian Hipotesis}

Penelitian ini menggunakan uji paired sample test sebagai pengujian hipotesis. Uji $\mathrm{t}$ digunakan untuk melihat perbedaan antara satu objek yang sama. Adapun kriteria pengambilan keputusannya yaitu dengan melihat nilai probability. Level kesalahan yang digunakan di dalam penelitian ini adalah sebesar 0,05 atau 5\%. Adapun hasil pengujian hipotesis di dalam penelitian ini adalah sebagai berikut:

\section{Tabel 3 Hasil Paired T Test}

\begin{tabular}{|c|c|c|c|}
\hline & & t-stat & $\mathrm{df}$ \\
\hline Pair 1 & $\begin{array}{l}\text { Keagamaan Sebelum QH } \\
\text { - Keagamaan Setelah QH }\end{array}$ & $-29.452 * * *$ & 33 \\
\hline Pair 2 & $\begin{array}{l}\text { Pendapatan Sebelum QH } \\
\text { - Pendapatan Setelah QH }\end{array}$ & $-10.958 * * *$ & 33 \\
\hline Pair 3 & $\begin{array}{l}\text { Tabungan Sebelum QH - } \\
\text { Tabungan Setelah QH }\end{array}$ & $-6.576 * * *$ & 33 \\
\hline Pair 4 & $\begin{array}{l}\text { Shadaqah Sebelum QH - } \\
\text { Shadaqah Setelah QH }\end{array}$ & $-6.855 * * *$ & 33 \\
\hline
\end{tabular}

Sumber : Data Diolah, 2019

Keterangan : $\quad * * *, * *$ dan $*$ merupkan nilai signifikansi pada level $1 \%, 5 \%$ dan $10 \%$. DF adalah derajat kebebasan. $\mathrm{QH}$ adalah Qardun Hasan .

Berdasarkan Tabel 3 di atas, ditemukan bahwa terdapat perbedaan antara kegiatan keagamaan sebelum menerima pembiayaan Qardun Hasan dengan setelah menerima pembiayaan Qardun Hasan dengan t-statistik mencapai angka 29.452 dan signifikan pada level $1 \%$ sehingga $\mathrm{H} 1$ diterima. Selanjutnya pendapatan pedagang sebelum menerima pembiayaan Qardun Hasan juga memiliki perbedaan setelah pedagang menerima pembiayaan Qardun Hasan dengan t-statistik sebesar -10.958 dan signifikan pada level $1 \%$ sehingga $\mathrm{H} 2$ diterima. Hal yang sama juga terjadi pada tabungan pedagang yang memiliki perbedaan pada saat belum menerima pembiayaan Qardun Hasan dengan setelah menerima pembiayaan Qardun Hasan dengan t-statistic sebesar -6.576 dan signifikan pada level 1\% sehingga H3 diterima. Tingkat Shadaqah pada pedagang juga memiliki perbedaan sebelum dan setelah menerima pembiayaan Qardun Hasan dengan t-statistik -6.855 dan signifikan pada level 1\% sehingga $\mathrm{H} 4$ diterima. Secara keseluruhan Qardun Hasan memberikan dampak yang signifikan terhadap kesejahteraan pada pedagang.

\section{PENUTUP}

\section{Kesimpulan}

Berdasarkan hasil analisis data yang telah dilakukan, ditemukan bahwa terdapat perbedaan yang signifikan pada aktivitas keagaan, pendapatan, tabungan dan shadaqah pada pedagang sebelum dan setelah menerima pembiayaan Qardun Hasan. Hasil tersebut menunjukkan bahwa Qardun Hasan menjadi elemen yang dapat meningkatkan kesejahteraan pada pedagang kecil dan menengah

\section{Saran}

Disarankan kepada pada pedagang kecil dan menengah untuk menghindari riba dan menerima pembiayaan Qardun Hasan dalam menjalankan usahanya. Kemudian disarankan kepada pihak pemerintah terkait untuk mensosialisasikan pembiayaan Qardun Hasan kepada pedagang-pedagang kecil dan menengah. Disarankan kepada peneliti selanjutnya untuk menggunakan indikator lain dalam mengukur kesejahteraan, seperti kesehatam, pendidikan dan gaya hidup yang mungkin dapat digunakan. 


\section{REFERENSI}

Amin, H., Ghazali, M., \& Supinah, R. 2010. Determinants of Qardhul Hassan financing acceptance among Malaysian bank customers: An empirical analysis. International Journal of Business and Society, 11(1), 1.

Ashal, F. F., \& Nanda, T. S. F. 2018. Transaksi Pembiayaan Qardhul Hasan: Impact Keuangan Islam dalam Ekonomi Ril. Al Tijarah, 4(1), 54-63.

Assegaff, Y. U., \& N H, H. 2016. Performance Improvement for Micro, Small and Medium Enterprises (SMEs) with Social Financing Model.

Badan Pusat Statistik. (2019). www.bps.go.id

BAPPENAS. (2019). www.bappenas.go.id

Febianto, I., \& Ashany, A. M. 2015. The impact of Qardhul Hasan financing using Zakah funds on economic empowerment (Case study of Dompet Dhuafa, West Java, Indonesia). Asian Business Review, 1(1), 15-20.

Ghozali, Imam. 2016. Aplikasi Analisis Multivariete Dengan Program. IBM SPSS 23. (Edisi 8). Cetakan ke VIII. Badan Penerbit, Semarang.

Hardi, E. A. 2013. Analisis Pemberdayaan Masyarakat Muslim Miskin Melalui Qardul Hasan. Adzkiya: Jurnal Hukum dan Ekonomi Syariah, 1(2).

Mirachor, A., \& Iqbal, Z. 2007. Qardhul Hasan Microfinance. New Horizon, April-Juni.

Purwadi, M. I. 2014. Al-Qardh dan Al-Qardhul Hasan sebagai Wujud Pelaksanaan Tanggung Jawab Sosial Perbankan Syariah. Ius Quia Iustum Law Journal, 21(1), 24-42.

Rahardja, Prathama dan Mandala Manurung. (2001). Teori Ekonomi Makro. Jakarta; BPFE Universitas Indonesia.

Rambe, A., 2004. Alokasi Pengeluaran Rumah Tangga dan Tingkat Kesejahteraan (Kasus di Kecamatan Medan Kota, Sumatera Utara). Tesis. Sekolah Pascasarjana IPB. Bogor

Republik Indonesia, Undang-Undang 25 Tahun 1992 tentang Koperasi

Republik Indonesia, Undang-Undang No.10 Tahun 1998 tentang Perbankan

Republik Indonesia, Undang-undang Nomor 21 Tahun 2008 tentang Perbankan Syariah

Retnowati, Wahyu Indah. 2007. Hapus Gelisah dengan Sedekah. Jakarta: Qultum Media.

Riswandi, Dedi. 2015. Pembiayaan Qardhul Hasan di Bank Syariah Mandiri Kota Mataram. Jurnal Hukum Islam Vol. 14. No. 2. Desember 2015.

Sanusi, Muhammad. 2009. The Power Of Sedekah. Yogyakarta: Pustaka Insan Madani.

Sari, S. P. 2015. Pengaruh Pembiayaan Qardhul Hasan Terhadap Peningkatan Pendapatan Usaha Mustahik Zakat (Studi Kasus Dompet Peduli Umat Daarut Tauhiid Cabang Bogor). AL-INFAQ, 4(1), 57-93.

Sukirno. S. 2006. Ekonomi Pembangunan: Proses, Masalah, dan Dasar. Kebijakan. Jakarta: Prenada Media Group. 